УДК 796.854

DOI https://doi.org/10.26661/2663-5925-2020-1-18

\title{
АНАЛІЗ ЗМАГАЛЬНОЇ ДІЯЛЬНОСТІ ВИСОКОКВАЛІФІКОВАНИХ КІКБОКСЕРІВ
}

\author{
Рихаль В. I. \\ аспірант кафедри педагогіки і психологї \\ Львівський державний університет фізичної культури імені Івана Боберського \\ вул. Костюшки, 11, Львів, Україна \\ orcid.org/0000-0002-1670-0066 \\ rykhal8888@gmail.com \\ Окопний А. М. \\ кандидат наук з фізичного виховання і спорту, \\ доиент кафедри педагогіки і психології \\ Львівський державний університет фізичної культури імені Івана Боберського \\ вул. Костюшки, 11, Львів, Украӥна \\ orcid.org/0000-0001-5277-7952 \\ okopnuy@rambler.ru
}

Гуцул Н. 3.

кандидат наук з фізичного виховання і спорту, старший викладач кафедри фізичного виховання

Украйнська академія друкарства

вул. Під Голоском, 19, Львів, Украӥна

orcid.org/0000-0002-6080-2369

hutsulnatasha@rambler.ru

Ключові слова: кікбоксинг, техніка, підготовленість, змагальна діяльність.
У статті описано змагальну діяльність висококваліфікованих кікбоксерів, визначено ефективні технічні дії. Наведено аналіз літературних джерел i результатів констатуючого експерименту для визначення технічного арсеналу в змагальній діяльності. Систематизовано дані літератури щодо технічної підготовленості висококваліфікованих кікбоксерів. Виділено основні положення технічної підготовленості висококваліфікованих кікбоксерів.

Предметом дослідження є ефективні технічні дії в змагальній діяльності висококваліфікованих кікбоксерів. Мета дослідження - провести аналіз змагальної діяльності висококваліфікованих кікбоксерів із програми ISKA.

Mатеріали $і$ методи. У педагогічному дослідженні взяли участь 10 кікбоксерів високої кваліфікації, які знаходилися на етапі підготовки до вищих досягнень, мали звання МСУ і МСМК (по 5 осіб). Експерти проаналізували 44 поєдинки кікбоксерів високої кваліфікації (ISKA), під час яких розраховувалися коефіцієнти ефективності технічних дій.

Результати. Аналіз змагальної діяльності дозволив визначити відсоткове співвідношення ударів висококваліфікованих спортсменів. Найвищий показник ударів у голову складає 47\%, ударів руками - 44\%, прямі удари руками - 58\%, раун-кік - 68,5\%, в рівень тулуба - 96\%. Найвищий показник захистів за допомогою рук - 36\%; атакуючих дій $-50,7 \%$.

Висновки. За показниками змагальної діяльності кікбоксерів високої кваліфікації було виявлено використання ефективних технічних дій у нападі і в захисті у зв’язку із застосуванням під час змагального поєдинку 
технічних дій колінами i наданням правилами змагань можливості застосовувати один удар коліном у положенні захвату суперника.

Кікбоксери високої кваліфікації в змагальній діяльності використовують ефективні ударні технічні дії в нападі верхніми і нижніми кінцівками (44\% - удари руками, 36\% - удари ногами, 20\% - удари колінами). У змагальній діяльності серед захисних технічних дій найчастіше використовуються прийоми захисту за допомогою рук (36\%) порівняно із ногами (20\%), тулубом (28\%) і переміщеннями (16\%).

\title{
ANALYSIS OF THE COMPETITIVE ACTIVITY OF HIGHLY QUALIFIED KICKBOXERS
}

\author{
Rykhal V. I. \\ Postgraduate Student at the Department of Pedagogy and Psychology \\ Lviv State University of Physical Culture named after Ivan Boberskyj \\ Tadeusha Kostyushka str., 11, Lviv, Ukraine \\ orcid.org/0000-0002-1670-0066 \\ rykhal8888@gmail.com
}

Okopnyy A. M.

Candidate of Science of Physical Education and Sport, Associate Professor at the Department of Pedagogy and Psychology

Lviv State University of Physical Culture named after Ivan Boberskyj

Tadeusha Kostyushka str., 11, Lviv, Ukraine

orcid.org/0000-0001-5277-7952

okopnuy@rambler.ru

\section{Hutsul N. Z.}

Candidate of Science of Physical Education and Sport, Assistant Professor at the Department of Physical Education

Ukrainian Academy of Printing

Pid Holoskom St, 19, Lviv, Ukraine

orcid.org/0000-0002-6080-2369

hutsulnatasha@rambler.ru

Key words: kickboxing, equipment, training, competitive activity.
The article describes the competitive activities of highly qualified kickboxers, which determined the effective technical actions. The analysis of literature sources and results of the ascertaining experiment for definition of technical arsenal in competitive activity is presented. The data of the literature on the technical training of highly qualified kickboxers are systematized. The main provisions of technical training of highly qualified kickboxers are highlighted. The subject of the study is effective technical actions in the competitive activities of highly qualified kickboxers. The purpose of the study is to analyze the competitive activities of highly qualified kickboxers from the ISKA program.

Materials and methods. The pedagogical research was attended by 10 kickboxers of high qualification, who were at the stage of preparation for higher achievements, who had the titles of MSU and MSMK (respectively 5 people). The experts analyzed 44 matches of high-skilled kickboxers (ISKA) during which the coefficients of efficiency of technical actions were calculated. 
Results. The largest number of blows in competitive activities is directed by kickboxers in the head, but the efficiency ratio is the lowest (0.27). Strokes have a much higher efficiency (0.45), but are used much less than blows to the head. Strikes along the thigh have the highest coefficient of effectiveness (0.55), however, according to our observations, their use is associated with a high risk of counter-striking, because these strikes are performed at the same distance. The analysis of competitive activity allowed to determine the percentage of blows of highly qualified athletes. The highest rate of blows to the head is $47 \%$, blows to the hands $-44 \%$, direct blows to the hands $-58 \%$, raun-kick $-68.5 \%$, torso $-96 \%$. The highest rate of protection with the help of hands $-36 \%$; attacking actions $-50.7 \%$.

Conclusions. The competitive performance of highly qualified kickboxers has been found to use effective technical action in attack and defense, due to the use of technical action with the knees during a competitive fight and the provision of competition rules to allow one knee in the position of the opponent.

Highly qualified kickboxers in competitive activities use effective shock technical actions in the attack of the upper and lower extremities (48\% punches, 34\% - kicks, $20 \%$ - knee strikes) using the hands (36\%), compared with the legs $(20 \%)$, torso $(28 \%)$ and movements $(16 \%)$.

Постановка проблеми. Кікбоксинг є видом спорту, в якому велике значення мають технічні дії в змагальній діяльності. Прогрес спорту визначається на підставі об'єктивних знань про структуру змагальної діяльності і підготовленості спортсменів 3 урахуванням загальних закономірностей становлення спортивної майстерності й індивідуальних можливостей спортсменів-єдиноборців (В.Н. Платонов, 2004).

У змагальній діяльності відображаються позитивні та негативні сторони майстерності кікбоксерів, особливості сучасного кікбоксингу. Однак виявити їх не так просто через складність поєдинків під час змагань, тобто змагальної діяльності, яка складається 3 великої кількості найрізноманітніших аспектів процесу та способів їх вивчення.

У теорії і методиці кікбоксингу нами не виявлено чіткої концепції вивчення закономірностей розвитку змагальної діяльності. Результати розрізнених експериментальних і теоретичних досліджень цього напряму важко піддаються систематизації у зв'язку з різними цілями, завданнями і методами цих досліджень, що знижує цінність отриманих наукових даних.

Сучасні спортивні єдиноборства об’єднують у собі кращі технічні елементи та засоби тактичної боротьби з близьких по техніко-тактичному арсеналу видів спорту, що дає змогу застосовувати єдиний методологічний підхід до їх дослідження. Аналіз змагальної діяльності в кікбоксингу показує сталу тенденцію до зростання спортивної конкуренції. Оскільки шлях збільшення тренувальних навантажень має природні обмеження, актуальними є пошуки нових підходів до вдосконалення тренувального процесу.
Аналіз літературних джерел дає змогу зробити висновок, що одним із найбільш перспективних напрямів удосконалення спортивного тренування $є$ оптимізація алгоритму технічної підготовленості $[1 ; 4 ; 13 ; 14]$.

Згідно правил змагань із кікбоксингу ISKA [12] основними є ударні техніко-тактичні дії в змагальному поєдинку. У східних єдиноборствах (бокс, кікбоксинг, сават, тайський бокс) захисти належать до основних техніко-тактичних дій у змагальній діяльності. Первинність розгляду ударної техніки детермінується лише тим, що ударна дія виявляється первинною за змістом, бо у зв'язку з іiї відсутністю не використовують захисні дії. Дослідження змагальної діяльності кікбоксерів передбачало урахування класифікатора показників $[1-3,11]$.

Важливою характерною ланкою $є$ знання про структуру змагальної діяльності і підготовленості спортсменів, де враховують загальні закономірності становлення спортивної майстерності та індивідуальні особливості спортсменів, що є підставою для визначення прогресу у спорті [8]. У східних єдиноборствах змагальна діяльність віддзеркалює особливості техніко-тактичної майстерності спортсменів [6].

Аналіз змагальної діяльності аналізувався багатьма авторами: В.Н. Ост'яновим [6] у боксі, Сагатом Ной Кокламом у таїландському боксі муай тай [10], у кікбоксингу цим питанням займалися Ю.Н. Романов [9], С.О. Скирта [11], В.В. Клещьов [4] та інші.

Відеозапис поєдинків кікбоксерів аналізувався методом педагогічних спостережень. Ефективні технічні дії оцінювалися групою кваліфікованих експертів, при цьому реєструвалася кількість 
виконаних дій і хронометраж деяких із них, а саме кількість ударів за раунд і за бій загалом, кількість атак, контратак у нападі, захистів за допомогою рук, ніг і тулуба.

Варто зазначити, що не досить вивченим $\epsilon$ спектр напрямів для визначення ефективних технічних дій висококваліфікованих кікбоксерів у змагальній діяльності.

Мета - провести аналіз змагальної діяльності висококваліфікованих кікбоксерів із програми ISKA.

Завдання: визначити ефективні технічні дії висококваліфікованих кікбоксерів у змагальній діяльності.

Методи та організація дослідження: аналіз та узагальнення даних науково-методичної літератури; аналіз відеоматеріалів; педагогічне спостереження; методи математичної статистики.

Експерти проаналізовали 44 поєдинки кікбоксерів високої кваліфікації (ISKA) на чемпіонаті України, всеукраїнських змаганнях, IV ранзі, Всеукраїнських змаганнях «Кубок Карпат», на Чемпіонаті світу 3 кікбоксінгу за версією ISKA Орландо (США), під час якого розраховувалися коефіцієнти ефективності технічних дій.

Виклад основного матеріалу дослідження. За розрахунками коефіцієнту варіації вдалося виявити найбільш значущі фактори, які дозволяють досягти поставлених цілей і вирішити необхідні завдання. У математичній статистиці варіація вважається низькою, якщо $\mathrm{V}<33,3 \%$, якщо $\mathrm{V}>33,3 \%$, то варіація висока. У випадку високої варіації досліджувана сукупність даних $є$ неоднорідною, а тому не може бути узагальнюючим показником. Для цієї сукупності варто застосувати інші показники [11].

Варіативність вважається малою, якщо значення коефіцієнта варіації знаходиться в межах від 0 до 10\%, середньою - від 11 до 20\%, великою більше 21\%. Якщо коефіцієнт варіації має високі значення досліджуваних показників, то це характеризує можливість вирішення рухового завдання iз використанням різних варіантів. Тобто, зі зміною рівня розвитку таких показників результат змагальної діяльності і рівень техніко-тактичної підготовленості суттєво не змінюються.

За результатами змагальної діяльності ефективними технічними діями у нападі кікбоксери дозволили нам розрахувати коефіцієнт ефективності загальної кількості ударів $(0,43 \pm 0,02)$ у поєдинку спортсменів (табл. 1.). Так, коефіцієнт ефективності ударів у рівень голови дорівнював $0,27 \pm 0,03$; у рівень тулуба $-0,45 \pm 0,03$; у рівень стегна $-0,55 \pm 0,02$.

Аналіз змагальної діяльності дозволив визначити відсоткове співвідношення ударів у голову, тулуб і стегно - 47:37:16 (рис. 1).
Таблиця 1

Показники ефективних технічних дій у нападі кікбоксерів високої кваліфікації (n=10) $\mathbf{M} \pm \mathbf{m}$

\begin{tabular}{|c|c|c|c|}
\hline Показники & KEУ & $\boldsymbol{\sigma}$ & $\mathbf{V , ~ \%}$ \\
\hline Загальна кількість ударів & $0,43 \pm 0,02$ & 0,01 & 5,6 \\
\hline Удари у голову & $0,27 \pm 0,03$ & 0,07 & 24,1 \\
\hline Удари у тулуб & $0,45 \pm 0,03$ & 0,09 & 20,1 \\
\hline Удари у стегно & $0,55 \pm 0,02$ & 0,05 & 8,2 \\
\hline
\end{tabular}

Примітка: КЕУ - коефіиієнт ефективності ударів

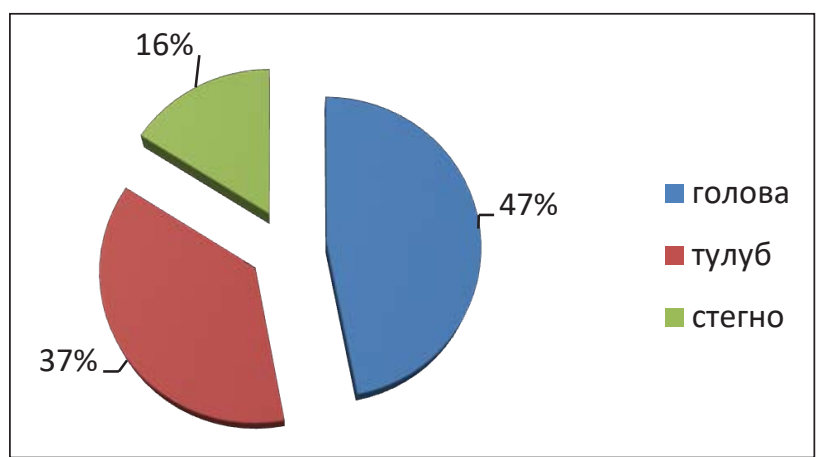

Рис. 1. Співвідношення ефективних ударів

у голову, тулуб і стегно кікбоксерів високої кваліфікації у змагальній діяльності

Отже, найбільша кількість ударів у змагальній діяльності спрямовується кікбоксерами у голову, але показник коефіцієнта ефективності - найнижчий $(0,27)$. Удари в тулуб мають значно вищий коефіцієнт ефективності $(0,45)$, але використовуються значно менше, ніж удари у голову. Найвищий коефіцієнт ефективності мають удари вздовж стегна $(0,55)$, проте, за нашими спостереженнями, їх використання пов'язане 3 високим ризиком зустрічного удару рукою, тому що ці ударні дії виконуються на одній і тій же дистанції.

За результатами змагальної діяльності було визначено кількісні показники відсоткового співвідношення ударів руками, ногами та колінами у кікбоксерів (рис. 2.). Кількість ефективних ударів руками складала 44\%, ногами - $36 \%$, колінами 20\%. Отримані дані свідчать про різне співвідношення ударних технічних дій верхніми і нижніми кінцівками кікбоксерів високої кваліфікації у змагальній діяльності.

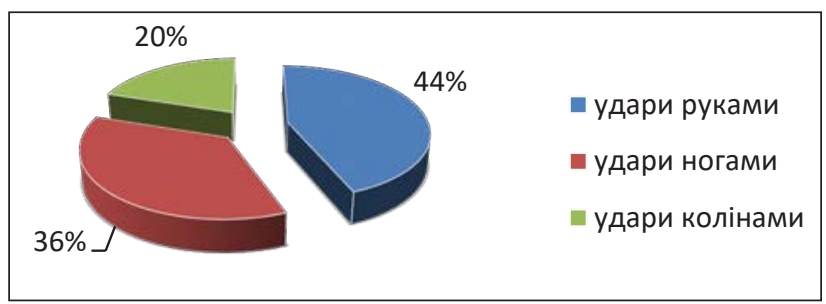

Рис. 2. Співвідношення ударів руками, ногами, колінами висококваліфікованими кікбоксерами у змагальній діяльності 
Аналіз дослідження ударів руками в нападі у кікбоксерів дозволив встановити, що коефіцієнт ефективності загальної кількості ударів руками склав $0,46 \pm 0,01$ (табл. 2). Ефективні удари в рівень голови становили $0,34 \pm 0,03$, у рівень тулуба $-0,78 \pm 0,04$. Отримані результати свідчать про виконання ударів руками в голову для того, щоб відвернути увагу супротивника від акцентованих ударів ногами і колінами в тулуб та ударів ногами вздовж стегна.

Таблиця 2

Показники ефективних технічних дій руками в нападі кікбоксерів високої кваліфікації $(\mathbf{n}=10) M \pm m$

\begin{tabular}{|c|c|c|c|}
\hline Показники & $\mathbf{K E У}$ & $\mathbf{\Sigma}$ & $\mathbf{V , ~} \%$ \\
\hline $\begin{array}{c}\text { Загальна кількість } \\
\text { ударів руками }\end{array}$ & $0,46 \pm 0,01$ & 0,03 & 8,4 \\
\hline Удари руками у голову & $0,34 \pm 0,03$ & 0,05 & 16,10 \\
\hline Удари руками у тулуб & $0,78 \pm 0,04$ & 0,1 & 13,0 \\
\hline Прямі удари руками & $0,31 \pm 0,02$ & 0,03 & 10,9 \\
\hline Бокові удари руками & $0,46 \pm 0,04$ & 0,04 & 9,8 \\
\hline Удари руками знизу & $0,46 \pm 0,05$ & 0,13 & 29,0 \\
\hline
\end{tabular}

Примітка: КЕУ - коефіцієнт ефективності ударів

У змагальній діяльності кікбоксери наносять ефективні прямі удари руками $(0,31 \pm 0,02)$; коефіці$\epsilon$ нт ефективності бокових ударів руками дорівнюе $0,46 \pm 0,04$, коефіцієнт ефективності ударів руками знизу дорівнює $0,46 \pm 0,05$. На нашу думку, це пов'язано 3 тим, що на ближній дистанції спортсмени виконують удари руками знизу та бокові удари.

За результатами дослідження було встановлено кількісні показники відсоткового співвідношення ударів руками: прямих, бокових ударів знизу, які становили 58\%, 34\%, 8\% відповідно (рис. 3).

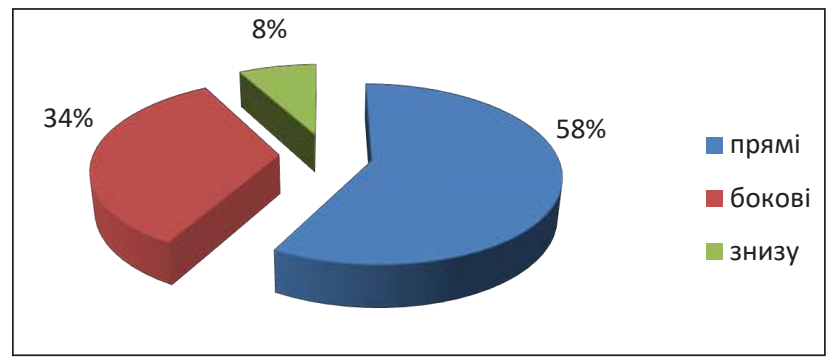

Рис. 3. Співвідношення ударів руками високваліфікованих кікбоксерів у змагальній діяльності

Проведення варіативного аналізу результатів дослідження коефіцієнтів ефективності ударів руками дозволило встановити коефіцієнт варіаціїна рівні $8,4 \%$, ударів руками в рівень голови - $16,10 \%$, ударів руками в рівень тулуба - $13,0 \%$, прямих $10,9 \%$, бокових ударів - 9,8\%, ударів знизу $-29,0 \%$ відповідно. Результати, які продемонстрували низьку варіативність прямих i бокових ударів руками спортсменів, може свідчити про їхній вагомий вплив на якість змагальної діяльності.

Таблиця 3

Показники ефективних технічних дій ногами в нападі висококваліфікованих кікбоксерів $(\mathrm{n}=10) \mathrm{M} \pm \mathbf{m}$

\begin{tabular}{|c|c|c|c|}
\hline $\begin{array}{c}\text { Показники } \\
\text { (загальна кількість) }\end{array}$ & КЕУ & $\boldsymbol{\sigma}$ & $\mathbf{V , ~} \%$ \\
\hline Удари ногами & $0,66 \pm 0,01$ & 0,03 & 7,1 \\
\hline Удари ногами в голову & $0,67 \pm 0,07$ & 0,09 & 29,0 \\
\hline Удари ногами в тулуб & $0,49 \pm 0,01$ & 0,08 & 22,8 \\
\hline Удари ногами у стегно & $0,64 \pm 0,01$ & 0,05 & 8,8 \\
\hline Фронт-кік & $0,48 \pm 0,05$ & 0,06 & 23,1 \\
\hline Раунд-кік & $0,61 \pm 0,03$ & 0,06 & 10,0 \\
\hline Сайд-кік & $0,47 \pm 0,02$ & 0,09 & 17,7 \\
\hline Бек-кік & $0,23 \pm 0,06$ & 0,09 & 36,3 \\
\hline
\end{tabular}

Примітка: КЕУ - коефіцієнт ефективності ударів

Дослідження результатів у змагальній діяльності ефективних техніко-тактичних дій ногами в нападі дозволило встановити, що коефіцієнт ефективності ударів ногами в голову найвищий $(0,67 \pm 0,07)$, нижчий показник ефективності ударів ногами в рівень стегна $(0,64 \pm 0,01)$ та в рівень тулуба $(0,49 \pm 0,01)$ що, на нашу думку, пов'язано із технічними складнощами виконання цього прийому та більш високими енергозатратами при використанні, ніж удари в тулуб і вздовж стегна.

Аналіз результатів дослідження (рис. 4.) дозволив визначити таке відсоткове співвідношення видів ударів ногами: фронт-кік - 29,7\%, раундкік - 68,5\%, сайд-кік - 1,4\%, бек-кік - 0,4\%.

Встановлено, що кікбоксери найчастіше використовують раунд-кік, який також є найбільш ефективним $(0,61 \pm 0,03)$. Визначено, що $62 \%$ раунд-кіків спрямовано вздовж стегна із зовнішньої та внутрішньої сторони. Значно менше кікбоксери використовують фронт-кік (коефіцієнт ефективності - $0,48 \pm 0,05$ ),

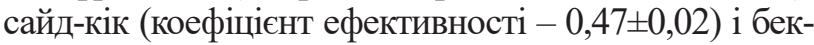
кік (коефіцієнт ефективності - 0,23 $\pm 0,06$ ).

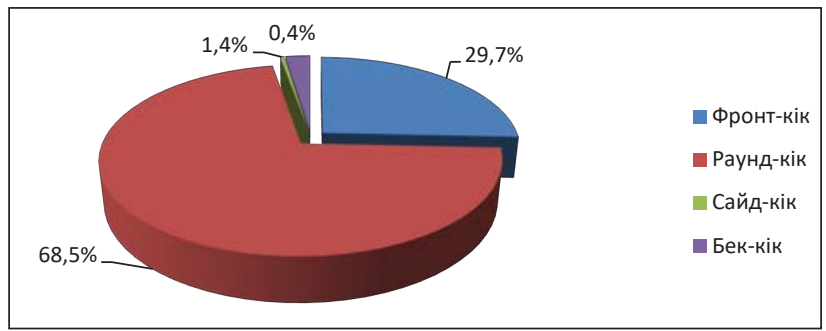

Рис. 4. Співвідношення ударів ногами високваліфікованих кікбоксерів у змагальній діяльності 
Отже, кікбоксери в змагальній діяльності використовують відносно прості у виконанні удари (раунд-кік і фронт-кік), а значно складніші в технічному виконанні удари (сайд-кік і бек-кік) застосовуються лише фрагментарно.

Під час дослідження коефіцієнтів варіації ефективності показника ударів ногами, ударів ногами у голову, тулуб і стегно та видів ударів ногами (фронт-кік, раунд-кік, сайд-кік, екс-кік, бек-кік) було встановлено, що коефіцієнти ефективності усіх досліджених нами ударів мають середню i високу варіативність, окрім ударів ногами $(\mathrm{V}=7,1 \%)$, ударів ногами в нижній рівень $(\mathrm{V}=8,8 \%)$ і раунд-кіку ( $\mathrm{V}=10,0 \%)$. Отже, сукупності показників ударів із низькою варіацією $е$ однорідними, тому вони можуть бути узагальнюючим показником технічної підготовленості кікбоксерів високої кваліфікації.

Відео-аналіз змагальної діяльності дозволив визначити відсоткове співвідношення ефективних бокових ударів колінами із захватом $(0,57 \pm 0,02)$ (табл. 4.). За даними результатів дослідження встановлено, що кікбоксерами $8,0 \%$ ударів колінами наноситься із захватом супротивника за голову (шию, плечі) однією або двома руками. Найбільш поширеними є прямі удари колінами із захватом супротивника 3 коефіцієнтом ефективності $0,70 \pm 0,02$.

Прямі удари колінами без захвату в середньому використовуються за ефективністю $0,50 \pm 0,07$. За нашими спостереженнями прямі удари колінами здебільшого використовуються назустріч або як завершальний удар у серії.

\section{Таблиця 4}

\section{Показники ефективних технічних дій} колінами в нападі кікбоксерів високої кваліфікації (n=10) $\mathbf{M} \pm \mathbf{m}$

\begin{tabular}{|c|c|c|c|}
\hline Показники & $\mathbf{K E \mathbf { ~ }}$ & $\boldsymbol{\sigma}$ & $\mathbf{V , ~ \%}$ \\
\hline Загальна кількість & $0,57 \pm 0,07$ & 0,04 & 8,9 \\
\hline Удари колінами у голову & $0,56 \pm 0,04$ & 0,12 & 22,0 \\
\hline Удари колінами у тулуб & $0,69 \pm 0,03$ & 0,04 & 8,9 \\
\hline $\begin{array}{c}\text { Прямі удари коліном } \\
\text { із захватом }\end{array}$ & $0,70 \pm 0,02$ & 0,04 & 8,0 \\
\hline $\begin{array}{c}\text { Прямі удари коліном } \\
\text { без захвату }\end{array}$ & $0,50 \pm 0,01$ & 0,04 & 9,5 \\
\hline $\begin{array}{c}\text { Бокові удари коліном } \\
\text { із захватом }\end{array}$ & $0,57 \pm 0,02$ & 0,06 & 9,4 \\
\hline
\end{tabular}

Примітка: КЕУ - коефіиієнт ефективності ударів

Аналіз виконання ударів колінами у рівень тулуба в змагальній діяльності кікбоксерів показав, що ці техніко-тактичні дії виконуються тільки із захватом, ефективність яких становила $0,69 \pm 0,03$. Також встановлено, що цей технічний прийом найчастіше використовується спортсменами у клінчі, у випадку, коли через щільний захват обома кікбоксерами відсутня можливість виконати інші види ударів.

Результати дослідження дозволили виявити, що лише 4\% ударів колінами спрямовуються у рівень голови, а решта (96\%) - у рівень тулуба (рис. 5).

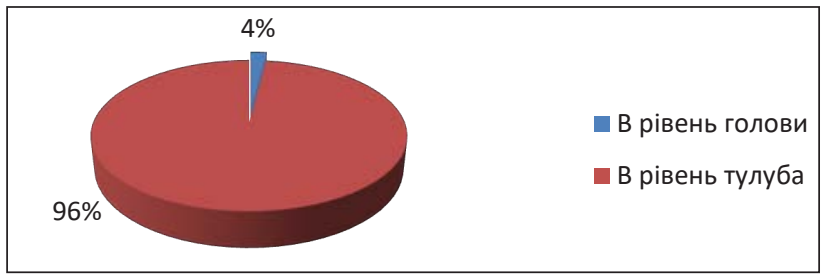

Рис. 5. Відсоткове співвідношення рівнів нанесення ефективних ударів колінами висококваліфікованих кікбоксерів у змагальній діяльності

Згідно з аналізом результатів дослідження коефіцієнтів варіації показників ефективності різновидів ударів колінами було визначено, що варіативність цих ударів $є$ низькою $(\mathrm{V}<10 \%)$, тому ці показники є узагальнюючими і можуть впливати на рівень технічної підготовленості.

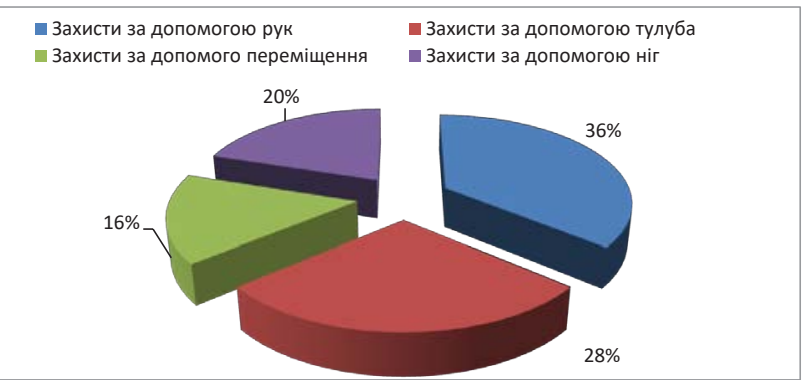

\section{Рис. 6. Ефективні технічні дії кікбоксерів у} захисті в змагальній діяльності

У змагальній діяльності найчастіше використовують прийоми захисту руками (36\%), рідше - тулубом (28\%). Найнижчі показники продемонстрував захист за допомогою ніг $(20 \%)$ та переміщення (16\%) (рис. 6). Аналіз змагальної діяльності дозволив встановити, що коефіцієнт ефективності захисних дій дорівнює $0,55 \pm 0,01$ (табл. 5).

Найбільш щільний захист спостерігається від ударів у голову (коефіцієнт ефективності $0,62 \pm 0,05)$, дещо нижчий коефіцієнт ефективності встановлено при виконанні захисних дій від ударів у рівень тулуба $(0,48 \pm 0,01)$. Результати дослідження дозволили зробити висновок про те, що найбільш вразливим під час атаки є рівень уздовж стегна, оскільки коефіцієнт ефективності захисних дій при цьому дорівнює $0,3 \pm 0,03$, що вказує на технічні складнощі для виконання захисних техніко-тактичних дій від ударів уздовж стегна. 
Таблиця 5

Ефективність технічних дій кікбоксерів у захисті в змагальній діяльності $(\mathrm{n}=10)$

\begin{tabular}{|c|c|c|c|}
\hline Показники & $\begin{array}{c}\text { КEУ } \\
(\mathbf{M} \pm \mathbf{m})\end{array}$ & $\mathbf{\Sigma}$ & $\mathbf{V , ~ \%}$ \\
\hline Захисти (загальна кількість) & $0,55 \pm 0,01$ & 0,03 & 9,0 \\
\hline $\begin{array}{c}\text { Захисти від ударів } \\
\text { у рівень голови }\end{array}$ & $0,62 \pm 0,05$ & 0,11 & 16,2 \\
\hline $\begin{array}{c}\text { Захисти від ударів } \\
\text { у рівень тулуба }\end{array}$ & $0,48 \pm 0,01$ & 0,14 & 27,3 \\
\hline $\begin{array}{c}\text { Захисти від ударів } \\
\text { у рівень стегна }\end{array}$ & $0,3 \pm 0,03$ & 0,07 & 25,7 \\
\hline
\end{tabular}

Примітка: КЕУ - коефіиієнт ефективності ударів

Досліджуючи рівень варіативності ефективності захисних дій, було виявлено, що ці показники не $\epsilon$ узагальнюючими і не можуть однозначно впливати на рівень техніко-тактичної підготовленості.

Аналізуючи технічні дії у нападі під час змагальної діяльності, встановлено, що кількість атакуючих бойових дій дорівнює при ефективності $0,59 \pm 0,02$ (табл. 6). Контратакуючі бойові дії реєструвалися фахівцями у двох варіантах - як контратака у відповідь і назустріч. Коефіцієнт ефек-

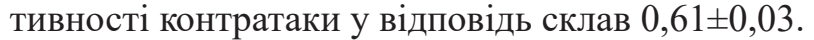

Таблиця 6

Ефективні технічні дії у нападі (атака, контратака) висококваліфікованих кікбоксерів у змагальній діяльності (n=10) $\mathbf{M} \pm \mathbf{m}$

\begin{tabular}{|c|c|c|c|}
\hline Показники & КЕУ & $\boldsymbol{\sigma}$ & $\mathbf{V}$ \\
\hline КЕАД & $0,59 \pm 0,02$ & 0,06 & 10,8 \\
\hline КЕКД & $0,61 \pm 0,03$ & 0,05 & 9,6 \\
\hline КЕКДН & $0,77 \pm 0,02$ & 0,08 & 10,9 \\
\hline
\end{tabular}

Примітка: КЕАД - коефіиієнт ефективності атакуючих дій; КЕКД - коефіціснт ефективності контратакуючих дій; КЕКДН-коефіцієнт ефективності контратакуючих дій у нападi

Коефіцієнт ефективності контратаки назустріч склав $0,77 \pm 0,02$. Відсоткове співвідношення бойових дій в середньому знаходилося на такому рівні: 50,7\% - атакуючі дії, 32,5\% - контратакуючі дії у відповідь, 16,8\% - контратакуючі дії назустріч (рис. 7).

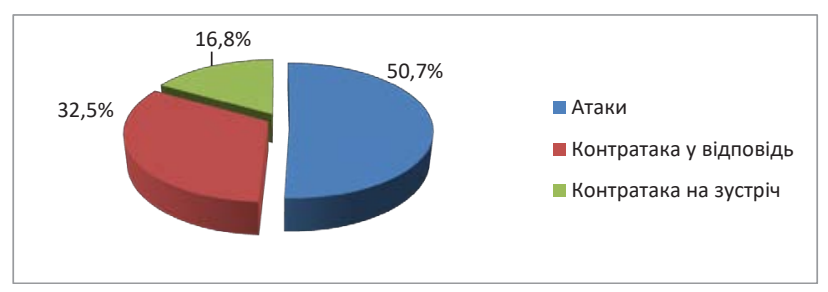

Рис. 7. Співвідношення видів активних дій (атака, контратака у відповідь, контратака назустріч) висококваліфікованих кікбоксерів у змагальній діяльності

Згідно з результатами аналізу змагальної діяльності кікбоксерів у змагальній діяльності можна зробити висновок, що у поєдинку кікбоксери високої кваліфікації більше використовують атакуючі, ніж контратакуючі дії, хоча коефіцієнт ефективності контратакуючих технічних дій вищий.

Досліджуючи варіативність активних дій у нападі кікбоксерів, нами було встановлено, що коефіцієнт варіативності атаки, контратаки у відповідь і контратаки назустріч мав низькі величини. Тому удосконалення цих показників активних дій позитивно впливає на вдосконалення рівня техніко-тактичної підготовленості кікбоксерів.

Висновки. За показниками змагальної діяльності кікбоксерів високої кваліфікації було виявлено використання ефективних технічних дій у нападі і в захисті у зв'язку із застосуванням під час змагального поєдинку технічних дій колінами і наданням правилами змагань можливості застосовувати один удар коліном у положенні захвату суперника.

Кікбоксери високої кваліфікації в змагальній діяльності використовують ефективні ударні технічні дії в нападі верхніми і нижніми кінцівками (44\% - удари руками, $36 \%$ - удари ногами, 20\% удари колінами). У змагальній діяльності серед захисних технічних дій найчастіше використовуються прийоми захисту за допомогою рук (36\%) порівняно із ногами (20\%), тулубом (28\%) і переміщеннями $(16 \%)$.

Подальший напрям досліджень полягає у визначенні ефективних технічних дій кікбоксерів на етапі попередньої базової підготовки з урахуванням вагових категорій, що дасть змогу вносити корекцію у навчальну програму ДЮСШ ISKA.

\section{ЛІТЕРАТУРА}

1. Гуцул Н.З., Скирта О.С., Рихаль В.І. Зіставлення показників техніко-тактичних дій кваліфікованих кікбоксерів на різних етапах багаторічної підготовки. Науковий часопис Нац. пед. ун-ту ім. М.П. Драгоманова. Серія 15 : зб. наук. пр. Київ : Вид-во НПУ імені М.П. Драгоманова, 2019. 5 (113) 19. С. 94-101.

2. Гуцул Н.З., Савчин М.П. Індивідуалізація техніко-тактичної підготовки кікбоксерів на основі стильових відмінностей. Науковий часопис Наи. пед. ун-ту ім. М.П. Драгоманова. Серія 15 : зб. наук. пр. Київ : Вид-во НПУ імені М.П. Драгоманова, 2016. 2 (71) 16. С. 98-101. 
3. Гуцул Н.3., Савчин М.П. Модельні характеристики спортивної підготовки кваліфікованих кікбоксерів індивідуальних стилів ведення бою. Науковий часопис Наи. пед. ун-ту ім. М.П. Драгоманова. Серія 15 : зб. наук. пр. Київ : Вид-во НПУ імені М.П. Драгоманова, 2016. 6 (76) 16. С. 41-45.

4. Клещев В.В., Блеер А.Н., Аджикаримов Т.З. Особенности соревновательной деятельности кикбоксеров в связи с фактором победы-поражения в поединке. Актуальныле проблемы спортивных единоборств. Москва, 2000. С. 63-68.

5. Лапшина Г.Г., Гуцул Н.З., Котельник А.М., Рихаль В.І. Основні підходи до урахування індивідуальних особливостей у підготовці кваліфікованих спортсменів із кікбоксингу. Вісник Запорізького національного університету : збірник наукових статей. Фізичне виховання та спорт. Запоріжжя : Запорізький національний університет, 2018. № 2. С. 96-105.

6. Ост'янов В.Н., Гриб А.І., Копачко О.В. Змагальна діяльність боксерів важких і легких вагових категорій. Педагогіка, психологія та медико-біологічні проблеми фізичного виховання і спорту. 2010. № 12. С. 94-98.

7. Платонов В.Н. Система подготовки спортсменов в олимпийском спорте. Общая теория и ее практические приложения. Київ : Олімп. л-ра, 2004. 808 с.

8. Платонов В.Н. Периодизация спортивной тренировки. Общая теория и её практическое применение. Київ : Олімп. л-ра, 2013. 624 с.

9. Романов Ю.Н. Особенности долговременной адаптации кикбоксеров в системе интегральной подготовки : автореф. дис. д-ра биологических наук. Спец. 03.03.01 «Физиология». Челябинск, 2014. 46 с.

10. Сагат Ной Коклам. Поединок в таиландском боксе. Серия «Мастера боевых искусств». Ростов н/Д : «Феникс», 2003. 338 с.

11. Скирта О.С. Вдосконалення техніко-тактичної підготовки кікбоксерів на етапі спеціалізованої базової підготовки : автореф. дис. канд. наук із фіз. виховання та спорту: [спец.]. 24.00.01 Олімпійський та професійний спорт. Дніпропетровськ, 2015. 20 с.

12. Федутенко В.В., Володченко О.В., Ящук В.С., Дворецький Г.Е. Кікбоксинг (версія ІСКА). Навчальна програма для дитячо-юнацьких спортивних шкіл (ДЮСШ). Київ, 2018. 73 с.

13. Evgen Prystupa, Andriy Okopnyy, Natalia Hutsul, Khrystyna Khimenes, Andriy Kotellnyk, Ihor Hryb, Maryan Pityn. Development of special physical qualities skilled kickboxers various style of competitive activity. Journal of Physical Education and Sport (JPES). Vol. 19 (Supplement issue 2). P. 273-280. doi:10.7752/jpes.2019.s2041.

14. Pityn M., Okopnyy A., Tyravska O., Hutsul N., Ilnytsky I. Dynamic of indexes of technical and tactical actions of qualified kickboxer individual fighting style. Journal of Physical Education and Sport (JPES). 17 (Supplement issue 3). P. 1024-1030. doi:10.7752/jpes.2017.s3157.

\section{REFERENCES}

1. Hutsul N.Z., Skyrta O.S., Rykhal V.I. (2019) Zistavlennia pokaznykiv tekhniko-taktychnykh dii kvalifikovanykh kikbokseriv na riznykh etapakh bahatorichnoi pidhotovky [Comparison of indicators of technical and tactical actions of qualified kickboxers at different stages of long-term training]. Naukovyi chasopys Nats. ped. un-tu im. M.P. Drahomanova. Seriia 15 : zb. nauk. pr. Kyiv : Vyd-vo NPU imeni M.P. Drahomanova. Vol. 5 (113) 19, p. 94-101.

2. Hutsul N.Z., Savchyn M.P. (2016) Indyvidualizatsiia tekhniko-taktychnoi pidhotovky kikbokseriv na osnovi stylovykh vidminnostei [Individualization of technical and tactical training of kickboxers on the basis of stylistic differences]. Naukovyi chasopys Nats. ped. un-tu im. M.P. Drahomanova. Seriia 15 : zb. nauk. pr. Kyiv : Vyd-vo NPU imeni M.P. Drahomanova. Vol. 2 (71) 16, p. 98-101.

3. Hutsul N.Z., Savchyn M.P. (2016) Modelni kharakterystyky sportyvnoi pidhotovky kvalifikovanykh kikbokseriv indyvidualnykh styliv vedennia boiu [Model characteristics of sports training of qualified kickboxers of individual fighting styles]. Naukovyi chasopys Nats. ped. un-tu im. M.P. Drahomanova. Seriia 15 : zb. nauk. pr. Kyiv : Vyd-vo NPU imeni M.P. Drahomanova. Vol. 6 (76) 16, p. 41-45.

4. Kleshchev V.V. Bleer A.N., Adzhikarimov T.Z. (2000) Osobennosti sorevnovatelnoy deyatelnosti kikbokserov $\mathrm{v}$ svyazi s faktorom pobedy-porazheniya $\mathrm{v}$ poedinke [Features of competitive activity of kickboxers in connection with the factor of victory-defeat in a duel]. Aktualnye problemy sportivnykh edinoborstv. Moskva. 1, p. 63-68.

5. Lapshyna H.H., Hutsul N.Z., Kotelnyk A.M., Rykhal V.I. (2018) Osnovni pidkhody do urakhuvannia indyvidualnykh osoblyvostei v pidhotovtsi kvalifikovanykh sportsmeniv z kikboksynhu [Basic approaches to taking into account individual characteristics in the training of qualified kickboxing athletes]. Visnyk Zaporizkoho natsionalnoho universytetu : zbirnyk naukovykh statei. Fizychne vykhovannia ta sport. Zaporizhzhia : Zaporizkyi natsionalnyi universytet. № 2. P. 96-105. 
6. Ostianov V.N., Hryb A.I., Kopachko O.V. (2010) Zmahalna diialnist bokseriv vazhkykh i lehkykh vahovykh katehorii [Competitive activity of boxers of heavy and light weight categories]. Pedahohika, psykholohiia ta medyko-biolohichni problemy fizychnoho vykhovannia i sportu. № 12, p. 94-98.

7. Platonov V.N. (2004) Sistema podgotovki sportsmenov v olimpiyskom sporte [The system of training athletes in Olympic sports]. Obshchaya teoriya i eè prakticheskiye prilozheniya. Kiïv : Olimp. 1-ra. 808 p.

8. Platonov V.N. (2013) Periodizatsiya sportivnoy trenirovki [Periodization of sports training]. Obshchaya teoriya i ee prakticheskoe primeneniye. Kiïv : Olimp. 1-ra. 624 p.

9. Romanov Yu.N. (2014) Osobennosti dolgovremennoy adaptatsii kikbokserov v sisteme integralnoy podgotovki [Features of long-term adaptation of kickboxers in the system of integral training]. Chelyabinsk.

10. Sagat Noy Koklam. (2003) Poedinok v tailandskom bokse [Fight in Thai boxing]. Seriya "Mastera boevykh iskusstv". Rostov n/D : "Feniks". 338 p.

11. Skyrta O.S. (2015) Vdoskonalennia tekhniko-taktychnoi pidhotovky kikbokseriv na etapi spetsializovanoi bazovoi pidhotovky [Improving the technical and tactical training of kickboxers at the stage of specialized basic training]. Dnipropetrovsk.

12. Fedutenko V.V., Volodchenko O.V., Yashchuk V.S., Dvoretskyi H.E. (2018) Kikboksynh (versiia ISKA) [Kickboxing (ISKA version)]. Navchalna prohrama dlia dytiacho-yunatskykh sportyvnykh shkil (DIuSSh). Kyiv, 73 p.

13. Evgen Prystupa, Andriy Okopnyy, Natalia Hutsul, Khrystyna Khimenes, Andriy Kotellnyk, Ihor Hryb, Maryan Pityn. (2019) Development of special physical qualities skilled kickboxers various style of competitive activity. Journal of Physical Education and Sport (JPES). Vol. 19 (Supplement issue 2). P. 273-280. doi:10.7752/jpes.2019.s2041.

14. Pityn M., Okopnyy A., Tyravska O., Hutsul N., Ilnytsky I. (2017) Dynamic of indexes of technical and tactical actions of qualified kickboxer individual fighting style. Journal of Physical Education and Sport (JPES). 17 (Supplement issue 3). P. 1024-1030. doi:10.7752/jpes.2017.s3157. 